\title{
HISTORIA HISTORIOGRAFII NA UNIWERSYTECIE WARSZAWSKIM
}

Katarzyna BŁACHOWSKA

\section{ABSTRACT}

THE HISTORY OF HISTORIOGRAPHY IN THE UNIVERSITY OF WARSAW

The history of historiography as an independent discipline was created in 1948-1958. In the academic year 1957/1958, the Historical Institute established the Department of History of Historiography and Methodology of History Teaching. The initiator of its creation and subsequently its first director was Wanda Moszczeńska (1896-1974), a student of Marcel Handelsman (1882-1945). The most successful period of the department was 1976-1997, when the Department was led by Jerzy Maternik, a student of Wanda Moszczeńska.

\section{KEYWORDS:}

history of historiography, Institute of History at the University of Warsaw 
Historia historiografii należy do młodszych dyscyplin badań nad przeszłością. Współczesny wybitny historyk historiografii, a także badacz dziejów tej dyscypliny Jerzy Maternicki wskazuje, że narodziła się ona: „w Polsce - podobnie jak to było w wielu innych krajach europejskich - po II wojnie światowej”'. Głównym przedmiotem refleksji badaczy historiografii jest dorobek historyków, przynależnych do epoki, która rozpoczęła się wraz z ukształtowaniem się badań przeszłości jako dyscypliny nauki. To zaś miało miejsce w wieku XVIII'.

Cechy, wyróżniające historiografię jako dyscyplinę nauki, nieco mimochodem, wskazał współczesny badacz dziejów myśli historycznej Krzysztof Pomian, w swej ocenie dzieła angielskiego historyka Edwarda Gibbona Zmierzch Cesarstwa Rzymskiego (The Decline and Fall of the Roman Empire; wyd.: 1788). Pomian pisa1:

dzieło Gibbona pozostaje po dziś dzień niedościgłym wzorem oraz podstawą przekonania, iż można ustanowić jakąś równowagę między trzema nieodłącznymi, choć nader często skłóconymi wzajemnie, aspektami pracy historyka: badaniem źródel, które stanowi o tym, iż jest on człowiekiem nauki; refleksją teoretyczną, która zmusza go do tego, by był filozofem; pisarstwem, które zapośrednicza przeciwieństwo między warsztatem a teorią, analizą a syntezą, doświadczeniem a rozumem, czyniąc tedy z dzieła historycznego, w którym równowaga taka została utrwalona, źródło nie tylko informacji, lecz nadto przemyśleń i przeżyć $[\ldots]$ czytelnika $[\ldots]^{3}$.

Wskazując trzy „skłócone wzajemnie” elementy naukowego wykładu przeszłości podstawę źródłową, podstawę teoretyczną, formę prezentacji - Krzysztof Pomian zdefiniował zasadniczy przedmiot badań historyków historiografii. Badają oni wagę każdego z tych elementów w pracach historyków eksplorujących wybrane zagadnienia z przeszłości i/bądź prezentujących ich całościowe objaśnienia. Głównym celem badań historyków historiografii jest odczytanie i objaśnienie perswazyjnej warstwy naukowego wykładu przeszłości, kształtującej „przemyślenia i przeżycia” odbiorcy indywidualnego i zbiorowego, a więc pamięć historyczną jednostek i społeczeństw.

Element stanowiący integralne dopełnienie badań historyków historiografii nad tekstami, w których historycy eksplorujący poszczególne zagadnienia prezentowali ich objaśnienia oraz historyków - autorów syntez, wyeksponował brytyjski historyk Edward H. Carr. On to, w snieco żartobliwej formie stwierdził: „gdy zaczynamy zajmować

1 J. Maternicki, Polska historia historiografii: Droga do profesjonalizacji, jej stan aktualny i perspektywy, [w: ] Historia historiografii i metodologia historii w Polsce i na Ukrainie, red. J. Maternicki, J. Pisulińska, L. Zaszkilniak, Rzeszów 2015, s. 17.

2 J. Serczyk, 25 wieków historii. Historycy i ich dzieła, Torun 1994, s. 190-194; Pomian K., Przeszłość jako przedmiot wiedzy, Warszawa 2010, s. 498-521.

3 K. Pomian, dz.cyt., s. 520-521. 
się historią [rerum gestarum], naszą pierwszą troską powinny być nie fakty, które ona zawiera, lecz historyk, który je opisał” ${ }^{4}$. Słowem: „Badaj historyka, zanim zaczniesz badać fakty" ${ }^{5}$. W wypadku historiografii brytyjskiej badanie owo prowadzi, jak na przykładzie jednej z prac Gerorge’a Macaulaya Trevelyana objaśnił Edward H. Carr ${ }^{6}$, do rozpoznania tradycji myśli politycznej, koncepcji metodologicznej, stanowiących punkt odniesienia dla formułowanych przez historyka interpretacji. W wypadku badań nad polską naukową historiografią rzecz jest bardziej skomplikowana. W aspekcie przedmiotu badań komplikacja wynika z faktu, że polska naukowa historiografia $\mathrm{w}$ wieku XIX kształtowała się i rozwijała bez instytucjonalnego wsparcia własnego państwa. W badaniach nad polską historiografią tego okresu dla poznania historyka nie wystarczy więc poznanie jego pochodzenia, światopoglądu i przekonań metodologicznych. Konieczne jest osadzenie jego aktywności w kontekście aktualnej polityki państwa zaborczego. Również zrozumienie polskiej historiografii wieku XX wymaga pogłębionego badania nie tylko losów historyków, lecz losów całej wspólnoty - narodu i państwa polskiego, a tym samym czynników warunkujących konceptualny i instytucjonalny kształt nauki historycznej. W taki sposób historia historiografii uprawiana jest w Instytucie Historycznym Uniwersytetu Warszawskiego od początku jej istnienia jako samodzielnej dyscypliny, mimo że status ten uzyskała w czasie bardzo trudnym dla polskiej nauki historycznej jako takiej - w latach 50. XX w. Stworzona jednak została przez uczoną, która - choć zafascynowana marksizmem - była jednocześnie wytrawnym warsztatowo badaczem, który uczyniła fundamentem nowej dyscypliny.

Na Uniwersytecie Warszawskim początki refleksji na temat polskiej naukowej historiografii sięgają jednak drugiej połowy XIX w. Zostały one sformułowane przez byłego gdy je opublikowal - profesora Uniwersytetu Warszawskiego. Był nim rosyjski uczony Nikołaj Kariejew (1850-1931), który w latach 1879-1884 pracował na warszawskiej uczelni, noszącej w tym czasie nazwę Cesarskiego Uniwersytetu Warszawskiego i będącej uczelnią rosyjską ${ }^{7}$. Po powrocie do Rosji, w 1886 r. na łamach

4 E. H. Carr, Historia. Czym jest. Wyktady im. George'a Macaulaya Trevelyana wygtoszone na uniwersytecie w Cambridge styczeń - marzec 1961, wydanie drugie opracowane przez R.W. Daviesa, redaktor naukowy J. Topolski, Poznań 1999, s. 33.

5 Tamże, s. 34.

6 Tamże, s. 33-35.

7 Cesarski Uniwersytet Warszawski został utworzony, po tym jak w ramach represji po upadku powstania styczniowego (1863-1864), w 1869 r. zamknięta została Szkoła Główna Warszawska, działająca od 1862 r., w której wykłady odbywały się w j. polskim. Cesarski Uniwersytet Warszawski był uczelnią rosyjską - wykłady odbywały się w j. rosyjskim i z Rosji przybywali zatrudnieni w nim profesorowie. Działał do r. 1915. Zob.: I. Ihnatowicz, Utworzenie Cesarskiego Uniwersytetu Warszawskiego w roku 1869, „Roczniki Uniwersytetu Warszawskiego” 1972, t. 12, s. 55-70; Tenże, Uniwersytet Warszawski w latach 1869-1899, w: Dzieje Uniwersytetu Warszawskiego 1807-1915, red. S. Kieniewicz, Warszawa 1981, s. 378-494; А. Баженова., Историки Императорского Вариавского университета 1869-1915: просвещение, наука, политика, Аюблин 2014. 
petersburskiego miesięcznika „Wiestnik Jewropy”, Kariejew opublikował artykuł Najnowszy zwrot w historiografii polskiej $(1861-1886)^{8}$, w którym zamieścił entuzjastyczną ocenę, wydanej w 1879 r. w Krakowie syntezy Dzieje Polski w zarysie ${ }^{9}$, autorstwa Michała Bobrzyńskiego, reprezentanta tzw. nowej szkoły (szkoły krakowskiej) w polskiej historiografii. Artykuł Kariejewa w 1888 r. ukazał się w języku polskim ${ }^{10}$.

Artykuł Nikołaja Kariejewa nie należy oczywiście do dorobku polskiej historii historiografii i jego ukazanie się nie miało wpływu na rozwój tej dyscypliny w polskiej nauce ${ }^{11}$, jednak ze względu na to, że materiały do artykułu autor ten zebrał, pracując jako profesor w Cesarskim Uniwersytecie Warszawskim należy o nim wspomnieć niejako z kronikarskiego obowiązku.

Istotny wpływ na kształtowanie się polskiej historii historiografii miało natomiast pionierskie w tej dziedzinie studium (jak swą pracę określił sam autor) Władysława Smoleńskiego (1851-1926) ${ }^{12}$ Szkoty historyczne $w$ Polsce $e^{13}$. Po raz pierwszy zostało ono opublikowane w warszawskim czasopiśmie „Ateneum”14. Publikacja miała miejsce w 1886 r., a więc w tym samym, w którym Nikołaj Kariejew opublikował swój artykuł w petersburskim „Wiestniku Jewropy”. W 1887 r. studium Smoleńskiego zostało wydane jako książka ${ }^{15}$. Współczesny historyk historiografii Jerzy Maternicki zwrócił uwagę na pewne słabości studium Władysława Smoleńskiego, stwierdzając, że:

Historiograficzny talent W. Smoleńskiego ujawnił się w pełni [ ... ] w napisanych później dwu mniejszych, znacznie dojrzalszych rozprawach; jedna poświęcona była Walerianowi Kalince, druga zaś Kazimierzowi Jarochowskiemul' ${ }^{16}$

8 Н.И. Кареев, Новейшая польская историография и переворот в ней (1861-1886), »Вестник Европь« 1886, Аекабрь, с. 535-588.

9 M. Bobrzyński, Dzieje Polski w zarysie, Kraków 1879. Kolejne wydania (poszerzone i częściowo zmienione): wyd. 2: t. 1-2, 1880-1881; wyd. 3: t. 1-2, 1887-1888. W j. rosyjskim: 1895.

10 M. I. Kariejew, Najnowszy zwrot w historiografii polskiej (1861-1886), Warszawa - Petersburg 1888. W 1890 r. Kariejew opublikował w j. rosyjskim pracę Upadek Polski w literaturze historycznej. W 1891 r. została ona wydana $\mathrm{w}$ j. polskim.

11 Artykuł Kariejewa jest obecnie wykorzystywany przez historyków historiografii jako tekst źródłowy.

12 A. Wierzbicki, Władysław Smoleński (1851-1926), [w:] Tenże, Poczet historyków polskich. Historiografia polska doby porozbiorowej, Poznań 2014, s. 141-150.

13 W. Smoleński, Szkoty historyczne w Polsce (główne kierunki poglądów na przeszłość), Warszawa 1887 - później kilka wydań, ostatnie: 1986.

14 J. Maternicki, Początki i rozwój polskich badań w dziedzinie historii historiografii (do 1939 r.), [w:] Historia historiografii i metodologia historii w Polsce i na Ukrainie, s. 113.

15 Zob. przypis 12 .

16 J. Maternicki, Początki i rozwój polskich badań..., s. 114. 
Prace te Smoleński opublikował w 1887 i 1888 r. ${ }^{17}$ Dekadę później, w 1897 r., inny warszawski historyk Tadeusz Korzon (1839-1918) ${ }^{18}$, opublikował na łamach wydawanego we Lwowie „Kwartalnika Historycznego”, artykuł Pogląd na dziatalność naukowa J. Lelewela ${ }^{19}$. Był on, jak zauważa Jerzy Maternicki: „w swoim czasie najlepszym opracowaniem naukowym poświęconym temu historykowi i jego dorobkowi twórczemu"20.

Władysław Smoleński i Tadeusz Korzon byli wybitnymi przedstawicielami tzw. warszawskiej szkoły historycznej, która uformowała się w drugiej połowie XIX w. Żaden z nich nie był jednak $\mathrm{w}$ tym czasie związany z Uniwersytetem Warszawskim. Nie był, bo być nie mógł, gdyż w latach 1869-1915 uczelnia w Warszawie była rosyjskim Cesarskim Uniwersytetem Warszawskim i Polaków w niej nie zatrudniano 21.

W 1915 r. Uniwersytet Warszawski na powrót stał się uczelnią polską, a od 1918 r. prężnie rozwijał się w niepodległym państwie polskim. Od początku istnienia polskiego Uniwersytetu Warszawskiego był z nim związany Marceli Handelsman (1882-1945). Wybitny uczony o niezwykle szerokich zainteresowaniach - jak napisał o nim współczesny badacz: „był jednym z ostatnich polskich polihistorów”22 wybitnym mediewistą, badaczem epoki nowożytnej i XIX w. Był też autorem pierwszego - od czasu wydanej w 1815 r. Historyki Joachima Lelewela (1786-1861) ${ }^{23}-$ podręcznika metodologii, który wyszedł spod pióra polskiego historyka. W pełnym kształcie został on opublikowany w $1928 \mathrm{r} .{ }^{24}$ Nadając mu tytul - Historyka - Marceli Handelsman wprost nawiązał do wielkiego poprzednika. O Historyce Handelsmana metodolog Tomasz Pawelec napisal: „ze współczesnej perspektywy wyraźnie widać skalę przedsięwzięcia, jakie w Historyce podjął warszawski uczony. Tak ambitnego i rozległego zadania analizy problemów teoretycznych historiografii na polskim gruncie

17 W. Smoleński, Stanowisko Waleriana Kalinki w historiografii polskiej, Warszawa 1887; Tenże, Stanowisko Kazimierza Jarochowskiego w historiografii polskiej, Warszawa 1888. Przedruk obu prac: Tenże, Pisma historyczne, t. III, Kraków 1901, s. 333-377, 379-409.

18 A. Wierzbicki, Tadeusz Korzon (1839-1918), [w:] Tenże, Poczet historyków polskich, s. 133-140; J. Kolbuszewska, Tadeusz Korzon (1839-1918). Między codziennościa, nauką a stużbą narodowi, Łódź 2011.

19 T. Korzon, Pogląd na dziatalność naukowa J. Lelewela, Lwów 1897, odbitka z „Kwartalnika Historycznego” tom. XI, zeszyt 2.

20 J. Maternicki, Początki i rozwój polskich badań..., s. 115.

21 W latach 1869-1915 w Cesarskim Uniwersytecie Warszawskim stanowisko profesora piastował tylko jeden Polak - Adolf Pawiński (1840-1896). J. Maternicki, Historia i życie narodu. Postawy i poglądy historyków polskich XIX iXX w., Rzeszów 2009, s. 365.

22 P. Węcowski, Marceli Handelsman (1882-1945), [w:] M. Handelsman, Historyka, oprac. P. Węcowski, Warszawa 2010, s. 343.

23 J. Lelewel, Historyka, tudzież o tatwym i pożytecznym nauczaniu historii, Wilno 1815.

24 M. Handelsman, Historyka. Zasady metodologii i teorii poznania historycznego. Podręcznik dla szkót wyższych, wydanie drugie poprawione i uzupełnione, Warszawa - Kraków - Lublin 1928 (wyd. 1.: 1921); reedycja wyd. 2.: Warszawa 2010 (w serii IH UW „Klasycy Historiografii Warszawskiej”). 
podjął się jedynie Lelewel”25. Marceli Handelsman zamieścił w swej Historyce podrozdział Zarys rozwoju historiografii polskiej, w którym omówił zagadnienie, poczynając od tekstów wytworzonych w średniowieczu, a kończąc na dorobku Joachima Lelewela ${ }^{26}$. Jednak w naukowo-dydaktycznej aktywności Marcelego Handelsmana, jak wskazał współczesny mediewista Piotr Węcowski: „Najbardziej twórcze okazały się dwa seminaria, określone przez Handelsmana jako »merowińskie « (prowadzone w latach 1921/2-1926) i »karolińskie «(od 1933/1934 r. aż do wybuchu wojny). Prace na nich pisali m.in. Stanisław Arnold, Aleksander Gieysztor, Tadeusz Manteuffel, Wanda Moszczeńska, Marian Henryk Serejski”27.

Po zakończeniu II wojny światowej Tadeusz Manteuffel (1902-1970) i Aleksander Gieysztor (1916-1999) odbudowali polską mediewistykę, natomiast Wanda Moszczeńska (1896-1974)28 i Marian Henryk Serejski (1897-1975) 29 zbudowali nową dyscyplinę nauk historycznych - historię historiografii.

Okres, w którym dzięki aktywności obojga uczonych historia historiografii zyskała status samodzielnej dziedziny badań historycznych Jerzy Maternicki datuje na lata $1948-1958^{30}$. Zbiegł się on więc z czasem głębokich przemian organizacyjnych i metodologicznych w polskiej nauce historycznej jako takiej. Za cezurę, wyznaczającą początek okresu formowania się historii historiografii jako samodzielnej dyscypliny Jerzy Maternicki wskazał wygłoszenie podczas VII Powszechnego Zjazdu Historyków Polskich we Wrocławiu (19-22.09.1948) przez Mariana Henryka Serejskiego referatu Problematyka historii historiografii ${ }^{31}$. Cezurę zamykającą czas formowania się historii historiografii wyznacza rok 1958, gdy w Instytucie Historycznym Uniwersytetu Warszawskiego zaczął działać - kierowany przez Wandę Moszczeńską - Zakład Historii Historiografii i Metodyki Nauczania Historii ${ }^{32}$.

VII Powszechny Zjazd Historyków Polskich: „miał dla polskiego środowiska historycznego znaczenie symboliczne. Było to pierwsze spotkanie polskich historyków

25 T. Pawelec, „Historyka” i refleksja metodologiczna Marcelego Handelsmana, [w:] M. Handelsman, Historyka, oprac. P. Węcowski, Warszawa 2010, s. 361.

26 Handelsman M., Historyka, s. 50-89.

27 P. Węcowski, dz. cyt., s. 343-344.

28 Por.: J. Maternicki, Wanda Moszczeńska (1896-1974) - wspóttwórczyni polskiej historii historiografi, Rzeszów 2017.

29 Por.: A. Wierzbicki, Marian Henryk Serejski jako animator polskiej historii historiografii po II wojnie światowej, [w: ] Historia historiografii i metodologia historii w Polsce i na Ukrainie, s. 37-50.

30 J. Maternicki, Polska historia historiografii..., s. 17; por.: Tenże, Narodziny polskiej historii historiografii (1945-1956), „Przegląd Humanistyczny” 1978, nr 1, s. 1-18 - przedruk [w:] Tenże, Kultura historyczna dawna i wspótczesna, Warszawa 1979, s. 307-332.

31 M. H. Serejski, Problematyka historii historiografii, [w: ] Pamiętnik VII Powszechnego Zjazdu Historyków Polskich we Wroctawiu 19-22 września 1948 r., t. II, z. 1, Warszawa 1948, s. 41-51.

32 J. Maternicki, Polska historia historiografii..., s. 18. 
po zakończeniu wojny”33. Symboliczne znaczenie miało też: „przemówienie ministra oświaty Stanisława Skrzeszewskiego, wygłoszone na otwarcie zjazdu, którego sens dobrze oddał tytuł, pod jakim ukazało się ono $\mathrm{w} \gg$ Głosie Ludu « [organ prasowy PPR]: W historiografii polskiej musi dokonać się przełom" ${ }^{34}$. W przemówieniu tym: „Skrzeszewski wyraźnie zaznaczył, że ostatecznym celem zmian w nauce powinna być »przodująca « marksistowska szkoła historyczna”35. Kilka miesięcy po zakończeniu Zjazdu we Wrocławiu, w dniach 20-21.04.1949 r., na posiedzeniu plenum Komitetu Centralnego - utworzonej w dn. 15.12.1948 r. - Polskiej Zjednoczonej Partii Robotniczej: „zadeklarowano potrzebę podjęcia ofensywy ideologicznej »na froncie naukowym «"36. Jej finał rozegrał się trzy lata później, gdy na zakończenie Pierwszej Konferencji Metodologicznej Historyków Polskich, która odbyła się w dniach 28.12.1951 r. - 12.01.1952 r. w Otwocku pod Warszawą, polscy historycy oficjalnie uznali marksizm-leninizm za jedyną naukową metodologię badań ${ }^{37}$.

Na konferencji w Otwocku zasadniczy przedmiot referatów i dyskusji stanowiły kwestie metodologiczne oraz ściśle z nim związane zagadnienie periodyzacji dziejów Polski. Poruszone zostały jednak również kwestie dotyczące historii polskiej historiografii. Podjął je Marian Henryk Serejski ${ }^{38}$, który od 1948 r. żywo angażował się w tworzenie nowej dyscypliny ${ }^{39}$. Podjęła je także Wanda Moszczeńska ${ }^{40}$, która wówczas jak zauważył jej uczeń i badacz drogi naukowej Jerzy Maternicki: „Po raz

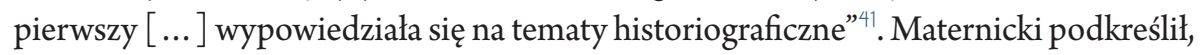
że w swym wystąpieniu na Konferencji w Otwocku Wanda Moszczeńska:

odnosząc się krytycznie do wcześniejszego dorobku polskiej nauki historycznej, daleka była od całkowitego jego odrzucenia $[\ldots]$ starała się w jakiejś mierze utrzymać ciągłość badań historycznych w Polsce ${ }^{42}$.

33 T. P. Rutkowski, Powszechne Zjazdy Historyków Polskich w Polsce Ludowej. Dokumenty i materiaty, wstęp, wybór i opracowanie T. P. Rutkowski, Torun 2014, s. 9.

34 Z. Romek, Historycy radzieccy o historykach polskich, [w:] Polska 1944/45-1989. Studia i materiaty, t. 4, Warszawa 1999, s. 183.

35 Tamże.

36 R. Stobiecki, Historia pod nadzorem. Spory o nowy model historii w Polsce (II połowa lat czterdziestychpoczątek lat pięćdziesiątych), Łódź 1993, s. 100.

37 List uczestników konferencji do prezydenta Rzeczypospolitej Polskiej Bolestawa Bieruta, [w:] Pierwsza Konferencja Metodologiczna Historyków Polskich, t. 2, Warszawa 1953, s. 559-560 list z dnia 12.01.1952 r. Szerzej nt. konferencji, zob.: R. Stobiecki, Pierwsza Konferencja Metodologiczna Historyków Polskich, [w:] Skryte oblicze systemu komunistycznego. U źródet zła..., red. R. Bäcker, P. Hübner, Warszawa 1997, s. 193-211; przedruk: Tenże, Historiografia PRL. Ani dobra, ani mądra, ani piękna ..., ale skomplikowana, Warszawa 2007, s. 96-116.

38 M. Serejski, Tradycja historiografii polskiej, [w:] Pierwsza..., t. 1., s. 123-126.

39 A. Wierzbicki, Marian Henryk Serejski..., s. 42.

40 W. Moszczeńska, Stosunek do dorobku historiografii polskiej, [w:] Pierwsza..., t. 1, s. 86-91.

41 J. Maternicki, Wanda Moszczeńska..., s. 69.

42 Tamże, s. 71. 
Była to postawa szczególna wśród ówczesnych historyków-marksistów, do których Wanda Moszczeńska się zaliczała, gdyż: „W czasach stalinowskich dominowała tendencja negatywna, znajdująca wyraz w potępianiu całego niemal dorobku $\gg$ historiografii burżuazyjnej «" ${ }^{43}$. Szerzej swe stanowisko uczona przedstawiła w 1955 r. w artykule, opublikowanym na łamach „Kwartalnika Historycznego” Czy historia historiografii jest waska specjalnością? ${ }^{44}$ Artykuł ten był głosem w polemice, którą w 1954 r. Stefan Kieniewicz (1907-1992) 45 podjął z Niną Assorodobraj (1908-1999) i Celiną Bobińską (1913-1997), zagorzałymi zwolenniczkami marksizmu i stosowania kryterium „postępowości” w badaniach nad historią historiografii ${ }^{46}$. Dziedziny, która w dobie gruntownych przemian polskiej nauki historycznej wprowadzonych do niej u progu lat 50., kształtowała się niejako naturalnie w tym sensie, że w nowej - marksistowskiej - rzeczywistości konieczne było określenie podstaw interpretacji bogatego dorobku polskiej nauki historycznej, rozwijającej się od schyłku XVIII do połowy XX w. Dyskusja, która odbyła się na łamach „Kwartalnika Historycznego” w latach 1953-1955 stanowiła odzwierciedlenie tego faktu.

Ostatecznie, jak stwierdził Jerzy Maternicki: „Wydarzeniem zamykającym pierwszy okres formowania się historii historiografii jako odrębnej subdyscypliny historycznej było utworzenie przez Wandę Moszczeńską [... ] pierwszego w Polsce

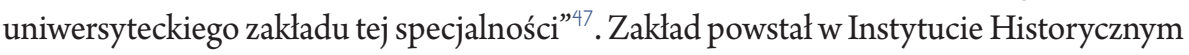
Uniwersytetu Warszawskiego, a stało się to dzięki wytrwałości Wandy Moszczeńskiej oraz postawie Aleksandra Gieysztora, ówczesnego dyrektora Instytutu Historycznego, który w pełni poparł jej dążenie do stworzenia uniwersyteckiego ośrodka badań w zakresie historii historiografii ${ }^{48}$. W ten sposób nowa dyscyplina badań - badań nad trzema „skłóconymi wzajemnie” elementami naukowego wykładu przeszłości, osadzeniem tegoż wykładu w teraźniejszości historyka go tworzącego, wpływem wykładu poszczególnych historyków na kształt pamięci historycznej społeczeństw - zyskała instytucjonalne podstawy rozwoju.

Można domniemywać, że zrozumienie Wandy Moszczeńskiej dla znaczenia prac badawczych nad tak pojmowaną historią historiografii, a przez to jej determinacja

43 Tamże.

44 W. Moszczeńska, Czy historia historiografii jest wąską specjalnością?, „Kwartalnik Historyczny” 1955, nr 2, s. $452-465$.

45 S. Kieniewicz, Jeszcze na temat zadań historii historiografii, „Kwartalnik Historyczny” 1954, nr 3, s. 197-200.

46 N. Assorodobraj, W sprawie kryterium postępowości w historii historiografii. W związku z książą M. H. Serejskiego o K. B. Hoffmanie, „Kwartalnik Historyczny” 1953, nr 4, s. 150-186; C. Bobińska, Spór o ujęcie pozytywizmu i historyków pozytywistów. W związku ze wstępem do reedycji W. Smoleńskiego „Szkót historycznych”, „Kwartalnik Historyczny" 1954, nr 1, s. 178-204.

47 J. Maternicki, Polska historia historiografii..., s. 18.

48 Tenże, Wanda Moszczeńska (1896-1974), s. 150. 
$\mathrm{w}$ dążeniu do utworzenia instytucjonalnych podstaw dla rozwoju tej dziedziny wynikała z osobistego doświadczenia. Historyk studia wyższe rozpoczęła w Moskwie w okresie I wojny światowej, a ukończyła w II Rzeczypospolitej na Uniwersytecie Warszawskim, na którym uzyskała też doktorat $\left(1923^{49}\right)$ i habilitację $\left(1934^{50}\right)$. W okresie międzywojennym pracowała jako nauczyciel w szkole powszechnej, w gimnazjach, na kursach dla dorosłych i była asystentem w Seminarium Historycznym Uniwersytetu Warszawskiego ${ }^{51}$. Słowem, doskonale poznała przez doświadczenie, zarówno trzy nieodłączne, nader często „skłócone wzajemnie” aspekty pracy historyka ${ }^{52}$, jak i znaczenie interpretacyjnego ksztaltu ich upowszechniania w formowaniu obrazu własnej przeszłości w oczach społeczeństwa.

W efekcie, utworzony dzięki zabiegom Wandy Moszczeńskiej zakład od początku swego istnienia - formalnie od roku akademickiego 1957/1958 - łączył dwie dyscypliny, co znalazło odzwierciedlenie w jego nazwie Zakład Historii Historiografii i Metodyki Nauczania Historii ${ }^{53}$. To połączenie dwóch, wydawać by się mogło odległych od siebie dziedzin - historii historiografii i dydaktyki (metodyki) historii - stało się niezwykle cenną cechą Instytutu Historycznego Uniwersytetu Warszawskiego. Historia historiografii, to - w kształcie jaki nadali jej twórcy Wanda Moszczeńska i Marian Henryk Serejski - dziedzina zajmująca się badaniem czynników ksztaltujących opowieść o przeszłości prezentowaną przez profesjonalnych historyków. Metodyka, czy szerzej dydaktyka historii to zaś dziedzina, w której uwagę poświęca się opracowaniu efektywnych form przekazu wiedzy i kształtowania umiejętności z zakresu historii na wszystkich poziomach nauczania. Współczesność pokazuje, że są to dziedziny ściśle ze sobą powiązane.

Pierwotne połączenie we wspólnej jednostce organizacyjnej badań nad historią historiografii oraz metodyki (dydaktyki) nauczania historii pozostało po dzień dzisiejszy cechą szczególną Instytutu Historycznego Uniwersytetu Warszawskiego, powodującą, że badacze związani z Zakładem łączyli i łączą w swej naukowej aktywności obie dyscypliny. Z korzyścią szczególnie dla dydaktyki.

Utworzenie Zakładu Historii Historiografii i Metodyki Nauczania Historii, od 1961 Katedry, dało instytucjonalną podstawę rozwoju historii historiografii w Instytucie Historycznym Uniwersytetu Warszawskiego. Twórczyni Zakładu (Katedry), Wanda Moszczeńska, kierowała nim do roku 1966, w którym przeszła na emeryturę. Prace

49 Na podstawie: W. Moszczeńska, Rola polityczna rycerstwa wielkopolskiego w czasie bezkrólewia po Ludwiku Wielkim, „Przeglad Historyczny” 1925, s. 33-159.

50 Na podstawie: Tejże, Arystokracja państwa Franków za dynastii Merowingów, Warszawa 1932.

51 J. Maternicki, Wanda Moszczeńska, s. 25-29.

52 K. Pomian, dz. cyt., s. 520.

53 J. Maternicki, Wanda Moszczeńska, s. 150. 
badawcze w dziedzinie historii historiografii kontynuowali jej uczniowie - Jerzy Maternicki, związany z Zakładem (Katedrą) od 1957 r. i Maria Wierzbicka zatrudniona w 1963 r. W następstwie zmian organizacyjnych w 1976 r. utworzony został Zakład Historii Historiografii i Dydaktyki Historii, kierowany przez Jerzego Maternickiego do roku $1997^{54}$.

Kierując przez 20 lat Zakładem Historii Historiografii i Dydaktyki Historii Jerzy Maternicki stał się kontynuatorem idei swej mistrzyni Wandy Moszczeńskiej, łącząc w swej pracy naukowej historię historiografii z metodologią historii i przekładając je na dydaktykę tego przedmiotu. W dziedzinie historii historiografii publikował prace, które stanowią podstawę - niepowstałej jeszcze - syntezy polskich środowisk historycznych ${ }^{55}$. Jerzy Maternicki był także pionierem w powojennych badaniach nad konceptem „idei jagiellońskiej” w polskiej myśli historycznej XIX i początku XX w. Ich wyniki opublikował w latach 1977-1992 $2^{56}$, chociaż rozprawę „Idea jagiellońska” w historiografii polskiej do $1914 r$. przygotowal już w latach 1961-1963. W latach 60. publikacja opracowania poświęconego temu tematowi nie była jednak możliwa ${ }^{57}$.

$\mathrm{W}$ drugiej połowie lat 80. Jerzy Maternicki zainicjował w polskiej historii historiografii formę pracy, której współczesnym odpowiednikiem są granty badawcze. Stworzył i kierował prężnymi zespołami, które w latach 1986-1990 opracowały i wydały pod jego redakcją 5 tomów opatrzonych tytułem Środowiska historyczne II Rzeczpospolitej i w latach 1989-1990 5 tomów Tradycji grunwaldzkiej. Jednocześnie Jerzy Maternicki

54 Szczegóły nt. osadzenia Zakładu Historii Historiografii w strukturze organizacyjnej Instytutu Historycznego, por. Tamże, s. 172-173.

55 Tenże, Warszawskie środowisko historyczne 1831-1869, Warszawa 1970; Tenże, Idee i postawy. Historia i historycy polscy 1914-1918, Warszawa 1975; Tenże, Historiografia polska XX w., cz. 1: Lata 1900-1918, Wrocław 1982; Tenże, Wieloksztaltność historii. Rozważania o kulturze historycznej i badaniach historiograficznych, Warszawa 1986, 1990; Tenże, Historiografia i kultura historyczna. Studia i szkice, cz. 1-2, Warszawa 1990. Jerzy Maternicki zainspirował też badaczy na co dzień zajmujących się epoką średniowiecza do badań nad środowiskiem historyków warszawskich, zob.: Historycy warszawscy ostatnich dwóch stuleci, red. A. Gieysztor, J. Maternicki, H. Samsonowicz, Warszawa 1986. Bibliografia prac Jerzego Maternickiego z okresu pracy w Instytucie Historycznym Uniwersytetu Warszawskiego: E. Cesarz, Bibliografia prac Profesora Jerzego Maternickiego 1959-1999, [w:] Historia - poznanie i przekaz, red. B. Jakubowska, Rzeszów 2000, s. 11-37.

56 J. Maternicki, Michat Bobrzyński wobec tzw. idei jagiellońskiej. Ewolucja poglądów i jej uwarunkowania, „Przegląd Humanistyczny” 1977, nr 12, s. 131-142; Tenże, Józef Szujski wobec tzw. idei jagiellońskiej, [w:] Historia XIX $i$ XX wieku. Studia i szkice. Prace ofiarowane H. Jabłońskiemu w siedemdziesiąta rocznicę urodzin, Wrocław 1979, s. 41-55; Tenże, Początki mitu jagiellońskiego w historiografii polskiej XIX w. Karol Szajnocha i Julian Klaczko, „Przegląd Humanistyczny” 1988, nr 11-12, s. 33-48; Tenże, Stanistaw Smolka i powrót historiografii polskiej do mitu jagiellońskiego, „Przegląd Humanistyczny” 1989, nr 1, s. 83-101; Tenże, Kontrowersje wokót idei jagiellońskiej w historiografii polskiej przetomu XIX i XX w., „Przeglad Humanistyczny” 1992, nr 4, s. 17-29; Tenże, The Jagiellonian Idea: the History of the Myth and Its Political Aspects (up to 1918), „Polish Western Affairs” 1992, No 2, pp. 163-197.

57 Tenże, Wanda Moszczeńska, s. 169. 
kształcił na Uniwersytecie Warszawskim adeptów historii historiografii ${ }^{58}$. Seminarium doktorskie prowadził do roku 1999.

Okres kierowania przez Jerzego Maternickiego Zakładem Historii Historiografii i Dydaktyki Historii Instytutu Historycznego byl „złotym wiekiem” historii historiografii na Uniwersytecie Warszawskim. W 1993 r. Jerzy Maternicki opuścił swój Zakład, by przenieść się do Rzeszowa.

W ostatnich dwudziestu pięciu latach, chociaż blask historii historiografii w Instytucie Historycznym Uniwersytetu Warszawskiego znacznie przygasł, to badania historiograficzne są kontynuowane w Zakładzie Dydaktyki i Historii Historiografii (od 2014 r.), a cennym ich dopełnienie stanowią badania prowadzone w Zakładzie Historii XX wieku nad historią nauki polskiej.

58 M. Królikowska, Szkoła naruszewiczowska i jej miejsce w historiografii polskiej XIX wieku, Warszawa 1989; K. Błachowska, Narodziny Imperium. Rozwój terytorialny państwa carów w ujęciu historyków rosyjskich XVIII $i$ XIX wieku, Warszawa 2001. Pełne zestawienie prac doktorskich przygotowanych na seminarium w IH UW, zob.: E. Cesarz, Lista prac doktorskich wykonanych pod kierunkiem Prof. dra hab. Jerzego Maternickiego, [w:] Historia - poznanie i przekaz, s. 37-38. 